\title{
The Effect of Educational Media Development in Increasing Knowledge and Attitudes on Pregnancy Complications at Sayang Rakyat Hospital in Makassar
}

\author{
Stang Stang ${ }^{1}$, Debora Selin ${ }^{2 *}$, Suriah Suriah $^{3}$, Sumarni Marwang $^{4}$, Anwar Mallongi $^{5}$, Hasanuddin Ishak $^{5}$ \\ ${ }^{1}$ Department of Biostatistics, Faculty of Public Health, Hasanuddin University, Makassar, Indonesia; ${ }^{2}$ Department of Reproduction \\ Health, Faculty of Public Health, Hasanuddin University, Makassar, Indonesia; ${ }^{3}$ Department of Health Promotion, Faculty of \\ Public Health, Hasanuddin University, Makassar, Indonesia; ${ }^{4}$ Midwifery Study Program, Mega Rezky University, Makassar, \\ Indonesia; ${ }^{5}$ Department of Environmental Health, Faculty of Public Health, Hasanuddin University, Makassar, Indonesia
}

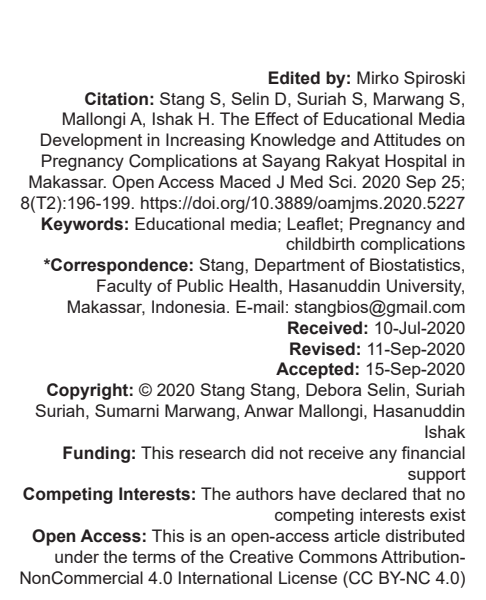

Introduction

Pregnancy occurs due to the meeting of sperm and egg cells. Pregnancy lasts for about 10 lunar months or 9 months calendar or 40 weeks 280 days. Pregnancy length is calculated from the $1^{\text {st }}$ day of last menstrual period [1]. Childbirth is the process of fetus or URI delivery with mature age (3742 weeks) or those that live outside the uterus through the birth canal or through another way, with or without assistance of cephalic presentation that takes place within $18 \mathrm{~h}$, without complications either on the mother and fetus [2], [3].

Maternal health issues continue as one of the sustainable development goals (SDGs) after the millennium development goals 2015, and the target is to reduce the maternal mortality rate (MMR) [4], [5]. The MMRs due to complications of pregnancy and childbirth in 2017 was around 830 women who died every day. The global maternal mortality ratio is
$216 / 100,000$ live births which are still far from the expected target. Globally, the SDGs target of 2030 for maternal mortality is $70 / 100,000$ live births [6]. Based on the data in the medical record of Sayang Rakyat Hospital, there were 85 obstetric complication cases $(38 \%)$ and $24(10.16 \%)$ prolonged labor cases in 2015 , 38 abortion cases $(36.02 \%)$ and 8 prolonged labor fetal distress cases $(6.06 \%)$ in 2016, 61 abortion cases $(57.00 \%)$, and 9 prolonged labor/fetal distress cases (8.41\%) in 2017 [7].

Many factors may affect the case of obstetric complications, namely: Lack of knowledge on the danger signs of pregnancy has been proven to be a cause of delay in seeking treatment/help. This is supported by the research of Ogu and Orazulike, 2017 [8], [9], which shows that delay in seeking help is recognized as an important determinant of maternal mortality. It also shows that providing health education is absolutely effective in increasing the knowledge on pregnancy of pregnant women [9], [10], [11]. Health education using leaflets is important for pregnant women to 
prevent complications and increase MMR and increase pregnant women's knowledge in dealing with the high risk of pregnancy and childbirth complications [12], [13].

\section{Materials and Methods}

This research was a quasi-experimental design with a pretest-posttest control group design that aims to assess the effect of certain treatments on a variable. This research involved two groups: An intervention group provided with leaflets and a control group provided with a book of maternal and child health $(\mathrm{MCH})$. Before the intervention, a measurement of knowledge and attitude (pre-test) was conducted for both the intervention group and the control group. After 2 weeks of intervention, the measurement was conducted to both knowledge and attitudes (post-test) in each group.

This research was conducted at Sayang Rakyat Hospital in Makassar, South Sulawesi. This place was chosen because the case of pregnancy and childbirth complications was still quite high compared to other hospitals in Makassar.

The research population was all 1-3-trimester pregnant women who examined their pregnancies at Sayang Rakyat Hospital on March to May 2020. The research sample was some of the 1-3-trimester pregnant women who examined their pregnancies at Sayang Rakyat Hospital. The data analysis used Wilcoxon Signed Ranks Test and Mann-Whitney test with SPSS software.

\section{Results}

The process of educational media development is a modified leaflet from the $2016 \mathrm{MCH}$ handbook of Ministry of Health of the Republic of Indonesia and making of Counseling Event Unit. The $\mathrm{MCH}$ handbook is modified into a leaflet with several improvements. In preparing this modified leaflet, the researchers involved several parties at Sayang Rakyat Hospital, including Hospital Health Promotion (PKRS) team, the Midwives in charge of the midwifery department, and several pregnant women.

Bivariate analysis was performed to determine differences in knowledge and attitudes about pregnancy complications before and after being provided with leaflet. The results of the bivariate analysis using the Wilcoxon test are as follows:

In Table 1, with the results of Wilcoxon signed ranks test, the knowledge variable obtained $p=0.000$ that was smaller than $\alpha=0.05$. It could be concluded that there were differences in maternal knowledge about complications of pregnancy and childbirth before and after being provided with leaflet intervention of $\mathrm{MCH}$ handbook modification.

Statistical test results on the attitude obtained $p=0.000$, in which smaller than $\alpha=0.05$. It could be concluded that there were differences in the attitudes of mothers regarding complications of pregnancy and childbirth before and after being provided with leaflet intervention of $\mathrm{MCH}$ handbook modification. Bivariate analysis was performed in the control group to determine differences in knowledge and attitudes about pregnancy complications before and after being provided with $\mathrm{MCH}$ handbook. The results of the bivariate analysis using the Wilcoxon test are as follows:

Table 1: Analysis of differences in knowledge and attitudes before and after the leaflet intervention at Sayang Rakyat Hospital in 2020

\begin{tabular}{llll}
\hline Variable & & Test results & \\
\cline { 3 - 4 } & & $\mathrm{Z}$ & $\mathrm{p}$ \\
\hline Knowledge & Pretest-posttest & -4.547 & 0.000 \\
Attitude & Pretest-posttest & -4.714 & 0.000 \\
\hline
\end{tabular}

In Table 2, with the results of the Wilcoxon signed ranks test, knowledge variable obtained $p=0.000$ that was smaller than $\alpha=0.05$. It could be concluded that there were differences in maternal knowledge about complications of pregnancy and childbirth before and after the control group who was only provided with the $\mathrm{MCH}$ handbook.

Table 2: Analysis of differences in knowledge and attitudes before and after being provided with $\mathrm{MCH}$ handbook at Sayang Rakyat Hospital in 2020

\begin{tabular}{llll}
\hline Variable & & Test results & \\
\cline { 3 - 4 } & & $\mathrm{Z}$ & $\mathrm{p}$ \\
\hline Knowledge & Pretest-posttest & -3.857 & 0.000 \\
Attitude & Pretest-posttest & -3.163 & 0.002 \\
\hline
\end{tabular}

Statistical test results on attitude obtained $p=0.002$ that was smaller than $\alpha=0.05$. It could be concluded that there were differences in the attitudes of pregnant women regarding complications of pregnancy and childbirth before and after the control group who was only provided with $\mathrm{MCH}$ handbook. To determine the differences in knowledge and attitudes between the intervention group and the control group, two analyses were conducted by comparing knowledge and attitudes between the intervention and control groups before (pre-test) and after (post-test) the intervention. The results of the analysis can be seen in Table 3:

Table 3: Analysis of differences in knowledge and attitudes before and after being provided with $\mathrm{MCH}$ handbook at Sayang Rakyat Hospital in 2020

\begin{tabular}{lll}
\hline Variable & Test results & Sig \\
\cline { 2 - 3 } & $\mathrm{Z}$ & \\
\hline Knowledge & -1.789 & 0.074 \\
Pre-test & -2.048 & 0.041 \\
Post-test & & \\
Attitudes & -2.399 & 0.016 \\
Pre-test & -3.451 & 0.001 \\
Post-test & \\
\hline
\end{tabular}

Based on Table 3 using the Mann-Whitney test, it showed that the comparison of knowledge between the intervention and control groups before 
the intervention obtained $p=0.074$. This was $>0.05$ which meant the intervention and control groups had no difference in knowledge. Whereas after the intervention, the comparison of knowledge between the intervention and control groups obtained $p=0.041$. This was smaller than 0.05 which meant the intervention and control groups had differences in knowledge.

The comparison analysis results of attitudes between the intervention and control groups before the intervention obtained $p=0.016$. This was smaller than 0.05 which meant the intervention and control groups had differences in attitudes. After the intervention, the results of attitudes comparison between the intervention and control groups obtained $p=0.001$. This was smaller than 0.05 which meant the intervention and control groups had differences in attitudes.

\section{Discussion}

Leaflet is media of delivering health information through folded sheets. Leaflet is a publication media in the form of paper sheet with a certain size, can be folded (generally, 2-3 folds) or not. The advantages of using this media, including the target, could adjust as well as learned independently and practically because it reduced the need to take notes. The target also could see the contents while relaxed, it was very economical and provided detailed information that was not provided verbally.

The results of knowledge comparative analysis before and after the intervention with the Wilcoxon signed ranks test showed that there were significant differences in both the intervention group and the control group. Although each group had a significant increase in knowledge, the intervention group provided with leaflets had a greater increase in knowledge. For the knowledge comparative analysis between the intervention and control groups using MannWhitney test, significant results were was obtained. By considering these two results, it can be concluded that the development of educational media in the form of leaflets had a positive effect in increasing pregnant women knowledge about complications of pregnancy and childbirth.

This research was in line with research conducted by Indrawati et al. [14] that there was a difference between the pre-counseling knowledge (leaflet) and post-counseling knowledge (leaflet) about increasing the knowledge of high-risk pregnant women with mediabased counseling $(p=0.000)$. Similar to the research conducted by Fitriani et al. [10], it also showed that the average knowledge of pregnant women before and after being provided with health education about high-risk pregnancies in the experimental group showed $p=0.000$. It meant that there was a significant difference between the average knowledge of pregnant women before and after being provided with health education about high-risk pregnancies. Health education with leaflets had an effect on the level of pregnant women knowledge regarding healthy lifestyles during pregnancy [15]. In addition, the research conducted by Jannah et al. [16] also showed an increase in students' knowledge after being provided with a leaflet about dental caries.

Development of educational media through leaflets modification of the $\mathrm{MCH}$ Handbook was done by adding material in the form of high-risk pregnancy, ways to prevent high-risk pregnancies, and avoid highrisk pregnancies. Modified leaflets can help pregnant women to easily understand the complications of pregnancy and childbirth. In addition to the complete material, the targets could also adjust and learn independently and practically because it reduced the need to take notes, they could easily see the content, and various information could be read by target group members to be discussed together. Last, it could provide detailed information which was not provided verbally.

The results of attitude comparative analysis before and after the intervention using Wilcoxon Signed Ranks Test showed that there were significant differences in both intervention and control groups. Although the significant change in the attitude of each group occurred, on the intervention group with leaflets, they had a greater positive attitude than the control group. The results of attitude comparative analysis between the intervention and control groups using the Mann-Whitney test obtained significant results. By considering these two results, it can be concluded that the development of educational media in the form of leaflets had a positive effect on the changes in pregnant women attitudes about complications of pregnancy and childbirth.

This research was in line with the research conducted by Indrawati et al. [14] that there was a difference between pre-counseling attitudes (leaflets) and post-counseling attitudes (leaflets) about increasing attitudes of high-risk pregnant women with media-based counseling $(p=0.000)$. This research was also in line with the research conducted by Jannah et al. [16], in which there were differences in attitude before and after health education about dental caries with a $p=0.0001$. Moreover, research conducted by Nurhasto et al. [17] about adolescents in Klaten showed that there was an effect of counseling about the dangers of free sex on adolescent attitudes. However, this research was actually different from the research conducted by Nurhamsyah et al. [18] that there was no effect of education on changes in student attitudes about the adolescent reproductive health triad.

\section{Recommendation}

It is expected that the development of educational media both modified leaflets and $\mathrm{MCH}$ handbook can be used as a reference and option in 
providing health education regarding complications of pregnancy and childbirth to pregnant women in improving knowledge and attitudes at Sayang Rakyat Hospital in Makassar.

Further research is needed regarding the management of pregnancy complications with educational media using application so that they can increase their knowledge and attitudes further about handling the pregnancy and childbirth complications.

\section{Conclusion}

Educational media on knowledge and attitudes about complications of pregnancy and childbirth has a positive effect in pregnant women at Sayang Rakyat Hospital in Makassar.

\section{References}

1. Hall JA, Benton L, Copas A, Stephenson J. Pregnancy intention and pregnancy outcome: Systematic review and meta-analysis. Matern Child Health J. 2017;21(3):670-704. https://doi. org/10.1007/s10995-016-2237-0 PMid:28093686

2. Adekanle D, Adeyemi A, Dairo F. Ante-partum haemorrhage and pregnancy outcome in lautech teaching hospital, Southwestern Nigeria. J Med Med Sci. 2011;2(12):1243-7.

3. Sudirman J, Sinrang AW, Marwang S, Nurlaily A, Sabar S, Astuti AT, et al. The analysis estradiol levels against sexual desire in perimenopause women in Makassar, South Sulawesi, Indonesia. Enferm Clin. 2020;30:350-3. https://doi.org/10.1016/j. enfcli.2019.07.117

PMid:32204184

4. Woldeyes WS, Asefa D, Muleta G. Incidence and determinants of severe maternal outcome in Jimma University teaching hospital, South-West Ethiopia: A prospective cross-sectional study. BMC Pregnancy Childbirth. 2018;18(1):1-12. https://doi. org/10.1186/s12884-018-1879-x

\section{PMid:29925329}

5. Nurhikmah SM, Tahir A, Stang, Suriah RT, Manyullei S. The roles of responsive and empathy of midwives in antenatal care visit of pregnant women in pangkep regency. Interciencia J. 2020;45(1):168-81.

6. Alkema L, Chou D, Hogan D, Zhang S, Moller A, Gemmill A, et al. Global, regional, and national levels and trends in maternal mortality between 1990 and 2015, with scenario-based projections to 2030: A systematic analysis by the UN maternal mortality estimation inter-agency group. Lancet. 2016;387(10017):462-74. https://doi.org/10.1016/ s0140-6736(15)00838-7

\section{PMid:26584737}

7. Rekam Medik Rumah Sakit Umum Daerah Sayang Rakyat, Makassar; 2018.

8. Ogu R, Orazulike N. Reducing maternal mortality: Awareness of danger signs in pregnancy. Asian J Med Health. 2017;6(1):1-8. https://doi.org/10.9734/ajmah/2017/35022

9. Sudirman J, Sampara N, Mawang S, Passe R, Aswan R, Ahmad M. The analysis of reducing blood glucose levels of diabetics with diabetes mellitus by giving a secang wood stew (Caesalpinia sappan L.) to menopausal women in Makassar city. Enferm Clin. 2020;30(2):506-9. https://doi.org/10.1016/j. enfcli.2019.07.148 PMid:32204224

10. Fitriani E, Uami S, Rahmalia S. Efektifitas pendidikan kesehatan tentang kehamilan resiko tinggi terhadap pengetahuan ibu hamil. Jom Psik. 2012;1(2):1-8.

11. Amiruddin R, Palutturi $S$, Rahman $S A$. Increasing midwifery skil for pregnancy health care with ammuntuli bija tianang na bejabeja model. Indian J Public Health Res Dev. 2018;9(9):364-8. https://doi.org/10.5958/0976-5506.2018.01025.2

12. Mukhoirotin M, Rahmat I, Siswosudarmo R. Pengaruh pendidikan kesehatan terhadap kecemasan primigravida dalam menghadapi persalinan. J Kesehatan Reprod. 2015;1(3):16674. https://doi.org/10.22146/jkr.5747

13. Nurhikmah, Stang, Suriah, Abdullah T, Arundhana SM. The effect of counselling intervention during antenatal care on the knowledge and attitude about danger signs in pregnancy: A cross-sectional study in takalar regency. J Pharm Nutr Sci. 2020;10(2):1-5.

14. Indrawati ND, Damayanti FN, Nurjanah S, Muhammadiyah U. Peningkatan pngetahuan dan sikap ibu hamil resiko tinggi dengan penyuluhan berbasis media. In: Rakernas Aipkema. 2016. p. 267-75. https://doi.org/10.26714/jk.7.1.2018.69-79

15. Yusuf NN, Isnaeni Y. Pengaruh Pendidikan Kesehatan dengan Leaflet terhadap Tingkat Pengetahuan Ibu Hamil Mengenai Pola Hidup sehat Selama Kehamilan di Puskesmas Mergangsan, Sekolah Tinggi IImu Kesehatan Aisyiyah Yogyakarta; 2014. https://doi.org/10.30989/mik.v6i1.172

16. Jannah Z, Kasjono HH, Kes M. Perbedaan Pengaruh Pendidikan Kesehatan Tentang Karies Gigi Melalui Media Buku Cerita Bergambar dan Leaflet terhadap Pengetahuan, Sikap, dan Perilaku Anak Sekolah Dasar di Kabupaten Malang, Muhammadiyah Surakarta; 2016. https://doi.org/10.14710/ jgi.3.1.121-125

17. Nurhasto IY, Wahyuningrum D, Handayani S. Pengaruh penyuluhan tentang bahaya seks bebas terhadap sikap remaja dalam seks bebas di SMA N I wedi klaten. J Health Sci. 2016;4(8):2-8. https://doi.org/10.35874/jic.v2i1.51

18. Nurhamsyah D, Mendri NK, Wahyuningsih M. Pengaruh edukas terhadap perubahan pengetahuan dan sikap mahasiswa tentang TRIAD kesehatan reproduksi remaja (KRR) di fakultas ilmu sosial dan ekonomi Universitas Respati. J Keperawatan Respati. 2017;2(2):67-83. https://doi.org/10.24198/jkp.v5n1.1 